\title{
Fairness of Dismissal as a Sanction for Misconduct in South African Labour Law
}

\author{
Prof. CM van der Bank
}

Vaal University of Technology

Executive Dean: Human Sciences

riana@vut.ac.za

\author{
Doi:10.5901/ajis.2014.v3n1p139
}

\begin{abstract}
In determining whether a dismissal based on misconduct is fair, all the facts surrounding the misconduct must be considered. The Commission for Conciliation, Mediation and Arbitration (CCMA) commissioner had to determine whether or not a misconduct dismissal was fair. CCMA unfair dismissals arbitration proceedings constituted hearings de novo which meant that the CCMA commissioner had to make his finding, as to the fairness of the dismissal, not on the basis only of evidence led at the internal disciplinary hearing, but on the basis of all evidence led at the CCMA arbitration proceedings, including evidence led that had not been led at the internal disciplinary hearing. The Constitutional Court had to decide whether a commissioner at CCMA arbitration was performing an administrative function. The Court concluded that the commissioner arbitration was an administrative action but that Promotion of Administrative Justice Act No.3 of 2000 is not applicable to CCMA arbitration awards. The fairness of dismissing an appellant from employment must be tested against the review standard laid down by the constitutional court in Sidumo.
\end{abstract}

Keywords: unfair dismissals, procedure, reasonableness, judgment and arbitration

\section{Abbreviations}

CCMA: Commission for Conciliation, Mediation and Arbitration

LRA: $\quad$ Labour Relations Act

PAJA: $\quad$ Promotion of Administrative Justice Act

\section{Introduction}

The South African Labour Law and practice has changed significantly in a number of areas. South Africa may be described as a country of vast contrasts. The context in which labour relations emerges at different workplaces varies considerably (Finnemore, 1999). The make-up of today's workplace is characterised by the use of a wide array of modern working practices and technologies (Holman et al., 2005). Labour legislation, the impact of unions on all types of organized and unorganised employees, and the variety of issues, topics and goals that characterize these relationships, are among the factors that make labour relations such a challenging study (Bezuidenhout et al., 1999). Factors contributing to these changes were court decisions and socio-economic pressure brought about by global economic down turns such as apartheid.

Section 23(1) of the Constitution provides that everyone has the right to fair labour practice. The reference to 'everyone' in the provision might appear misleading as the section clearly refers to "labour practices', which may be defined as "the practices that arise from the relationship between workers, employers and their respective organization" (Cheadle et al., 2002). At present the South African labour scene is in an area of contention as never before. Dismissals could also constitute an unfair dismissal and the employee is then also entitled to various remedies (Van Jaarsveld et al., 1998). Many dismissals are challenged in court. The individualistic and voluntary, rights-based regulation of the employment relationship has drastically altered since the emergence of trade unionism and the increased intervention of the State in the sphere of employment by means of legislation.

Misconduct is one of three grounds recognized by the Labour Relations Act 66 of 1995 as justifying the dismissal of an employee, the others being incapacity or poor work performance and operational requirements Grogan (1999). Misconduct is prevalent in every workplace and its consequences may have far reaching implications, an employer has to adopt measures to curb misconduct (Van Zyl et al., 2008). This is done by implementing disciplinary rules in the form of a disciplinary code or a code of conduct. 
Dismissals further endorse the idea that, as a means of enforcing workplace discipline, dismissals should be considered as a sanction of last resort (Grogan, 1999). The Labour Relations Act Code of Good Practice is contained in Schedule 8 and provides guidelines to the interpretation and application of the statutes in terms of which they are issued. Their status is something less than that of the legal provisions contained in the body of a statute; they may be regarded as having quasi-statutory force (Kantor, 2001).

\section{Figure 1:}

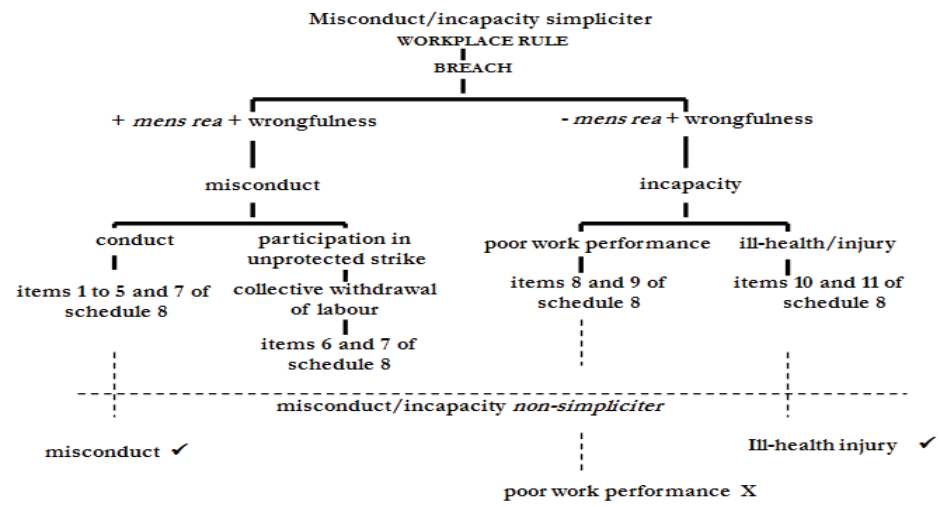

Employers must take account of the Code when managing discipline and incapacity. The key principle in this code is that employers and employees should treat one another with mutual respect (Nel, 2002). In determining whether the dismissal was a fair dismissal and whether the sanction of the dismissal was fair in a particular instance, the CCMA commissioner was required to Refer to the decision of the employer, in the sense that the CCMA commissioner should regard the decision as to whether or not dismissal was a fair sanction, in a particular instance, as falling primarily within the discretion of the employer and as set-aside able only if such decision did not fall within the boundaries of a "reasonable" decision, notwithstanding the CCMA commissioner's own view as to the fairness of the dismissal. Certain disputes (usually of major import), if not resolved by the CCMA in conciliation, may be referred to the Labour Court after which these cases can be taken on appeal to the Labour Appeal Court (Barker, 1999).

\section{Case Study}

Sidumo and Congress of SA Trade Unions v Rustenburg Platinum Mines Ltd, the CCMA and Moropa NO (2008) 19 SALLR 35 (CC) the following pertinent facts appear in this case:

The applicant Mr Sidumo was employed by the respondent employer, Rustenburg Platinum Mines Ltd in December 1985 as part of the latter's security services. In January 2000 Mr Sidumo was transferred to the Waterval Redressing Section where he was responsible for access control, whereby he controled the metals which were valuable and constituted the core business of Rustenburg Platinum Mines. Sidumo's main duty was to safeguard the precious metals of the mine through detailed compulsory search procedures for all persons leaving the section. His duties entailed an individual search of each person in a private cubicle with close personal inspection plus a metal detector scan.

As a consequence of a decline in its production, the employer had over three days in April 2000, resorted to video surveillance at various points which revealed that of 24 specifically monitored instances, Sedumo had conducted only one search in accordance with the established procedures. On eight occasions Sedumo had conducted no search at all and on 15 other searches he allowed persons to sign the search register without conducting any search at all. The employer charged Sedumo with the following misconduct:

- Negligence by not following established procedures in terms of the Protection Services Department search procedure. This caused prejudice or possible prejudice to the Company in terms of production loss.

- Failure to follow established procedures in terms of the Protection Services Department search procedures.

Sedumo had been found guilty by the employer of the judgment and principle and dismissed on 26 June 2000. Mitigating factors were considered and the applicant's internal appeal were unsuccessful and he then referred an unfair dismissal dispute to the CCMA. The CCMA per Maropa C found that the applicant employee had correctly been found guilty of misconduct, but that the dismissal was not an appropriate and fair sanction and therefore reinstated the applicant 
employee with three months' compensation and subject to a written warning valid for three months.

The respondent employer try to set the CCMA arbitration aside by the Labour Court but the court could not find any reviewable irregularity and dismissed the review application. Then the respondent employer appealed against the Labour Court judgment to the Labour Appeal Court. This court questions the CCMA commissioner's reasons for reinstating the employee but agreed with the commissioner's finding that the dismissal was too harsh a sanction (Van Zyl et al., 2008).

The respondent employer then appealed against the Labour Appeal Court's judgment to the Supreme Court of Appeal and that court upheld the appeal and overturned the decision of both the Labour Court and the Labour Appeal Court and substituted the CCMA commissioner with a determination that the dismissal of the applicant employee was a fair dismissal. The applicant employee then applied to the Constitutional Court for leave of appeal against the Supreme Court of Appeal's judgment.

For the Constitutional Court to have jurisdiction to entertain the appeal against the Supreme Court of Appeal judgment it must be on one or more constitutional issues (Van Zyl et al., 2008). The first constitutional issue was the interpretation and application of the 1995 Labour Relations Act and the Promotion of Administrative Justice Act No 3 of 2000 , both of which statutes had been enacted to give effect to the rights contained in, respectively, s 23 and s 33 of the Constitution. The Constitution states that everyone has the right to administrative action that is lawful, reasonable and fair, and that everyone adversely affected by an administrative decision is entitled to written reasons for it (Ackermann et al., 2006).

The Constitution also states that Parliament has to give effect to this right by means of legislation. Parliament has done so by means of the Promotion of Administrative Act, 200 (also known as "PAJA") which seems to be a codification or compilation of the right to administrative justice. PAJA seeks to realise a vision of open and accountable governance and a system of administrative justice that is fair and just (Devenish, 2001). Although the rules of administrative justice are focused on officials performing public functions, it makes sense for a private individual making decisions to involve and safeguard himself from judicial interference at a later stage (Ackerman et al., 2006). However, experience in many countries has indicated that laws such as PAJA, at a practical level are less successful in achieving their objectives (Devenish et al., 2001).

The second constitutional issue was the powers and functions of courts, in this case the powers and functions of the Labour Court and the Labour Appeal courts which have the same status as the High Court and the Supreme Court of Appeal. The Constitutional Court rejected the finding of the Supreme Court of Appeal "defence to employer" approach. The Commissioner of the CCMA acts under the auspices of the Commission, for Conciliation, Mediation and Arbitration and should approach a dismissal with a "measure of defence" (Sedumo) because it is primarily the function of the employer to decide on proper sanction. The commissioner need not be persuaded that the dismissal is the only fair sanction. The employer must establish that it was a fair sanction. In President of the RSA v SARFU 1999 (4) SA 147 (CC) the court considered the issue of prejudice and the duty to act fairly. The true test as confirmed in President of the RSA $v$ SARFU 1999 (4) SA 147 (CC) the important constituent element of the test was that the commissioner must be a person who was reasonable, objective and informed and who would entertain a reasonable apprehension (Rudd, 2005). The requirements of natural justice obliged a functionary to act fairly whenever a decision which is likely to prejudice another is taken by such a person (Du Preez v Truth and Reconciliation Commission 1996 (8) BCLR 1123 (C). The Constitutional Court rejected the differential approach. The Bill of Rights serves as a touchstone for measuring the constitutionality (and acceptability) of laws and administrative acts of government (Ackermann et al., 2006). Section 23 of the Constitution guarantees the right to fundamental fair labour practices; therefore the applicant employee's right to security of employment and the right not to be unfairly dismissed (The Constitution of the Republic of South Africa, 1996). It does not only give effect to the constitutional rights to labour relations but also provides a legislative framework within which such rights can be exercised (Mubangizi, 2004). Section 185 of the1995 LRA provides that every employee has the right not to be unfairly dismissed and gives effect to section 23 of the Constitution.

\section{Rejection by the Constitutional Court of "Defence to Employer" Approach}

Where an employee claims that he has been unfairly dismissed, he can refer the unfair dismissal dispute to the CCMA and the CCMA commissioner is then required to determine whether a disputed dismissal is fair or not. South African law together with both English and American law adheres in principle to the test of reasonableness of the decision-making process (Poolman, 1985). The commissioner has to determine the dismissal dispute as an impartial adjudicator. There is nothing in the constitutional and statutory process that suggested that in determining the fairness of a dismissal that the commissioners have to approach the matter from the perspective of the employer. The commissioner has to determine 
the dismissal dispute as an impartial adjudicator. The changing dispensation in South Africa introduced the concept of fairness (Nel, 2002). Therefore the Constitutional Court concluded that any suggestion by the Supreme Court of Appeal that the deferential approach is rooted in the prescripts of the Labour Relations Act cannot be sustained.

\section{Figure 2:}

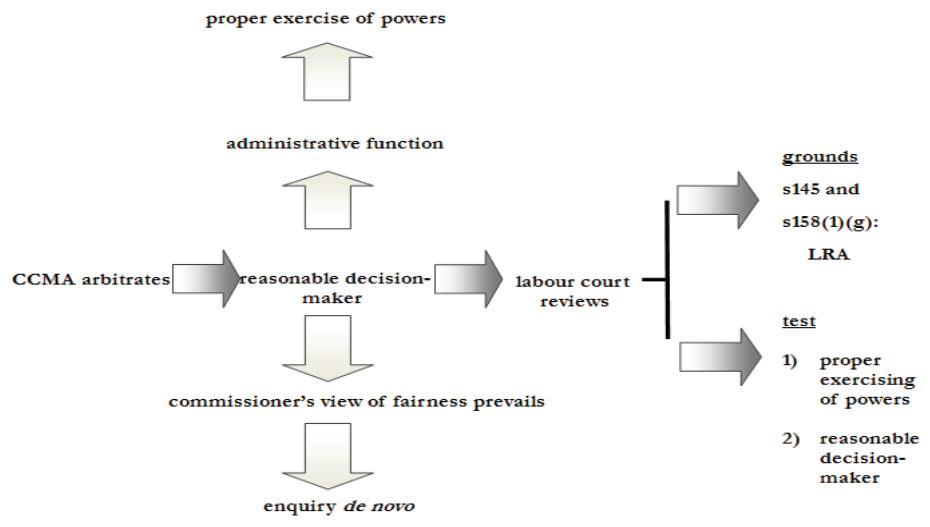

Item 7(b)(iv) of the Code in Schedule 8 further states that "if a rule or standard was contravened, whether or not dismissal was an appropriate sanction for the contravention of the rule or standard". The principle that the penalty must fit the offence requires an employer to consider alternative sanctions before taking the decision to dismiss (Grogan, 1999). This means that the CCMA commissioner had to consider whether dismissal was "an" appropriate sanction. The use of "an" and not "the" was not decisive. "An" is used indefinite as opposed to "the" used definite. The Code in item 7 was merely a guide and cannot take precedence over the Constitution and the Commissioner in determining the fairness of a dismissal, should approach the matter from the perspective of the employer (Kantor, 2001). The Commissioner should therefore approach the dismissal with a measure of defence.

The Supreme Court of Appeal's approach was deferential with three motivations for it.

Firstly a textual motivation as set out in principle 57 of the SALLR report:

- S 188(2) of the 1995 LRA was of note, which section obliged commissioners in considering whether or not the reasons for a dismissal were fair, to take into account the Code of Good Practice;

- Item 7 (b)(iv) of the Code required the Commissioner to consider that the dismissal was "an" appropriate sanction (a guideline);

- The Code also stated that it was generally inappropriate to dismiss employees for a first offence unless a continued relationship would be intolerable; therefore a measure of subjectivity was bought into play. The primary assessment of intolerability was unavoidable and belonged to the employer.

Secondly the conceptual motivation for the deferential approach was based on:

- The concept of fairness was not absolute- it afforded a range of possible responses;

- The court had to recognize that there might be a range of possible decisions that the employer could take, some of which might be fair and some unfair;

- The court's duty was to determine whether the decision that the employer took fell within the range of decisions that might properly be described as being fair.

Thirdly the institutional motivation for deferential approach was based on:

- The solution to the problem of a flood of challenges to awards lay in pointing commissioners firmly to the limits of the statute;

- If commissioners could freely substitute their judgment and discretion for the judgment and discretion of the employer, employees would take every case to the CCMA.

The Constitutional Court rejected the deferential approach associated with reasonable employer test which test is not applicable in our law. The deferential approach which was associated with the so-called reasonable employer test was used in England. This test had its origins in s 57(3) of the country's Employment Protection (Consolidated) Act of 1978. This act determines the question whether the dismissal was fair or unfair after the employer has shown the reasons and also that the employer can satisfy the tribunal that in the circumstances that he acted reasonable in treating it as a 
sufficient reason for dismissing the employee. The English Courts had therefore resorted to the "band of reasonableness test" as described by Lord Denning in British Leyland UK Ltd v Swift(1981) IRLT 91.This approach of "band of reasonableness" had been extensively criticized in England on the basis that it did not allow for a proper balancing of the interests of employer and employee.

The Constitution and the 1995 LRA sought to redress the power imbalance between employers and employees. Not one of them afforded any preferential status to the employer's view on the fairness of a dismissal. The constitutional values and norm did not give pre-eminence to the views of either party to a dispute.

\section{Correct Approach to be Adopted by CCMA Commissioner in Determining whether Misconduct Dismissal was Fair}

In determining whether a dismissal based on misconduct is fair, all the facts surrounding the misconduct must be considered (Grossett, 2002). The CCMA commissioner has to determine whether or not a misconduct dismissal was fair. Section 138 of the 1995 LRA stated that the commissioner had to do this fairly and quickly. Firstly the commissioner has to determine whether or not misconduct had been committed on which the employer's decision to dismiss has been based. There must be an inquiry into whether there had been a workplace rule in existence and whether the employees have breached the rule.

This means that the CCMA arbitration proceedings constituted a hearing de nova. The commissioner determined whether the dismissal was fair. The employer has the right to make a decision of dismissal but the determination of its fairness was done by the commissioner. Ultimately the commissioner's sense of fairness was what had to prevail and not the employer's view. In approaching the dismissal dispute impartially, the commissioner should also take into account the totality of circumstances.

The rules to be followed by anyone who has to take a decision that may adversely affect the rights and interests of another (natural or juristic person) derive from the following questions:

- What is the decision that I have to take?

- Is the decision a lawful one?

- Do I have the necessary legal authority to take that decision? Do I have all the necessary facts at my disposal to take a proper decision or should I obtain more information?

- Will I be able to "hear the other side" or am I being presented with only one side of the story?

- Will I be exercising a free and unfettered discretion?

- Will I confine my judgments to matters relevant to the issue and not considered irrelevant material?

- Will I apply my mind to the matter at hand without acting as a mere "rubberstamp" or "going through the motions"?

- Will I be conveying my decision intelligibly and without undue delay to those concerned?

The following should be considered by the commissioner:

- The importance of the rule that had been breached;

- The reason why the employer had imposed the sanction of dismissal;

- The basis of the employee's challenge to the dismissal;

- The harm caused by the employee's conduct;

- Whether training and instruction might result in the employee's not repeating the misconduct;

- The effect of dismissal on the employee;

- The employee's long - service record.

The above list is not a numerous causa. The decision itself must be reasonably reconcilable with the process (i.e. the decision should not have been for such a nature that no reasonable person in the same circumstances would have arrived at). This will lead to the strengthening of democracy and in be line with the spirit of the Constitution which requires the Bill of Rights to be given horizontal effect.

\section{Was PAJA Applicable in Respect of the Review by the Labour Court of CCMA Arbitration Award?}

The Constitutional Court stated that the Supreme Court of Appeal had found that PAJA applied, because PAJA was the national legislation passed to give effect to the constitutional right in section 33 to just administrative action, and was required to "cover the field" and purported to do so, it also applied to CCMA commissioners' arbitration awards. 
The Constitutional Court rejected the finding of the Supreme Court of Appeal and found that PAJA did not apply to CCMA arbitration awards. Firstly the Constitutional Court had to decide whether a commissioner at CCMA arbitration was performing an administrative function. The Court concluded that the commissioner arbitration was an administrative action but that PAJA is not applicable to CCMA arbitration awards. PAJA was general legislation and not special or specialized negotiated legislation like the 1995 LRA which gives effect to the right to fair labour practices. Section 33 of the Bill of Rights (the section dealing with the right to constitutional fair administrative action) precluded specialized legislative regulation of administrative action. Section 145 of the 1995 LRA precluded general legislation such as PAJA. The courts applied the general legislation and unless specifically indicated, did not derogate from special legislation (Van Zyl, Rudd and Associates, 2008). In Sedimo, specialised provisions trumped the general provisions. The 1995 LRA was purposefully designed to provide accessible, speedy and inexpensive dispute resolution. Section 157(1) of the 1995 LRA provides a platform for forum-shopping.

The powers of the Labour Court in section 158 set out in the 1995 LRA were directed at remedying a wrong and provide finality speedily. This is contrary to the position under section 8 of PAJA where the Labour Court could set aside a CCMA arbitration award on review and could substitute the administrative decision. The powers of the Labour Court in the 1995 LRA therefore differed significantly from the powers of the court as set out in s8 of PAJA.

S210 of the 1995 LRA specifically provided that, if any conflict, relating to matters dealt with in the 1995 LRA, arose between the 1995 LRA and the provisions of any other law, the provisions of the 1995 LRA would prevail. The legislation had not, with the enactment of PAJA, amended or repealed s210 of the 1995 LRA.

The CCMA commissioner has also taken the view that the offence committed by the applicant employee had not gone to the heart of the relationship of trust between the parties. No evidence has been led at the CCMA arbitration proceedings to the effect that the respondent employer has suffered any loss as a consequence specifically of the applicant's neglect.

The Constitutional Court also agreed that describing the applicant employee's conduct as a mistake or unintentional erred was confusing and agreed with the Supreme Court of Appeal that the CCMA commissioner has.

On the third factor in the absence of dishonesty the Constitutional Court disagreed with the Supreme Court of Appeal's view that such factor was irrelevant, stating that the CCMA commissioner could not be faulted for considering the absence of dishonestly to be a relevant factor in relation to the misconduct.

On the issue of the breakdown of trust, the Constitutional Court agreed with the Supreme Court of Appeal that the CCMA commissioner had been wrong to conclude that the trust relationship might not have been breached as the applicant employee had been employed to protect the respondent employer's valuable property and had not done so. However, the Constitutional Court stated that what was stated above did not constitute the end of the inquiry as it was still necessary to weigh all the relevant factors together in light of the seriousness of the breach.

The absence of dishonesty on the part of the employee in casu was a significant factor in favour of the application of progressive discipline rather than dismissal (Van Zyl et al., 2008). The applicant employee had also falsely denied that he had received appropriate training, and this factor counted against him.

The Constitutional Court concluded that the CCMA commissioner had carefully and thoroughly considered the different elements of the Code and had properly applied his mind to the appropriateness of the sanction.

\section{Review Test: Sidumo Judgment}

In Ivan Myers v National Commissioner of the South African Police Service, The Safety and Security Sectoral Bargaining Council and Coen de Kock NO where the appellant was dismissed from his employment by the Police Services was decided that the fairness of the decision must be tested against the review standard laid down by the constitutional court in Sidumo. The test was formulated as follows:

'is the decision reached by the commissioner one that a reasonable decision-maker could not reach? Explaining the standard, the court said applying it would give effect not only to the constitutional right to fair labour practices, but also to the right to administrative action which is lawful, reasonable and procedurally fair. It must, therefore, follow that, to survive scrutiny, the decision to dismiss must be "reasonable" and reasonableness must be tested in the light of the facts and circumstances of a given case.

In its judgment the majority accepted that the sanction imposed on the appellant was a harsh sanction in Ivan Myers v National Commissioner of the South African Police Service, The Safety and Security Sectoral Bargaining Council and Coen de Kock NO but then added that it is not so unreasonable that it stands to be reviewed and set aside. The court 
further accepted that the decision was unreasonableness but not sufficiently unreasonable to warrant interference. The court inadvertently imported a higher standard that contemplated in Sidumo. It would mean that a dismissed employee seeking to set aside a dismissal, would have to show not only that the decision-maker's decision is unreasonable but that it is so unreasonable that it falls to be reviewed and set aside. But that is not the test by turning to the arbitration award; the supreme court of appeal has already indicated that the application of the test requires one to look at the decision and how the decision-maker came $t$ the conclusion to which he or she did. We are here dealing with a review and not an appeal, and therefore one is concerned with how the decision was arrived rather than the conclusion. Commissioner Strydom had little or no regard to the mitigating factors in the Ivan Myers case.

Having regard all the mitigating factors the test in Sidumo, a reasonable decision-maker would have had regard to all factors and could have come to a conclusion that the dismissal of the appellant was the appropriate sanction. The following order is made and the order of the labour appeal court is set aside and replace with the following:

- The first respondent's dismissal is declared to have been substantially unfair.

- The appellant is ordered to reinstate the first respondent to the position he held before the first respondent's dismissal.

- The order above is to operate with retrospective effect to the date of the dismissal.

- The first respondent is given a final written warning valid for a period of twelve months from the date of the order.

Ivan Meyers v The National Commissioner of the South African Police Service (2013) 24 SALLR 1 (SCA)

- The Sidumo test does not entail an enquiry whether:

- the decision is unreasonable and

- sufficiently unreasonable to warrant interference

(the view adopted by the majority in the labour appeal court judgment)

[The above amounts to a test of "gross unreasonableness", which is a higher standard than required in Sidumo]

\section{The Constitutional Judgment}

The deferential/reasonable approach was not to be applied by the CCMA commissioners in deciding whether or not a misconduct dismissal was fair and in particular, whether the sanction imposed by the employer was fair. The CCMA commissioner was not required to show deference to the decision of the employer but had to decide for himself, with reference to all the relevant circumstances, whether or not the misconduct dismissal and, in particular, the sanction, was fair.

CCMA unfair dismissals arbitration proceedings constituted hearings de novo which meant that the CCMA commissioner had to make his finding, as to the fairness of the dismissal, not on the basis only of evidence led at the internal disciplinary hearing, but on the basis of all evidence led at the CCMA arbitration proceedings, including evidence led that had not been led at the internal disciplinary hearing (Van Zyl et al., 2008).

The conduct by a commissioner of CCMA arbitration proceedings under the 1995 LRA did not constitute administrative action as envisaged by PAJA. Therefore PAJA was not applicable in respect of reviews by the Labour Court of CCMA arbitration awards (Van Zyl et al., 2008).

Reviews are governed by s145 of the 1995 LRA infused by the constitutional standard of reasonableness which standard entailed that the Labour Court has to apply the following test in determining whether or not the arbitration award was reviewable: Was the decision reached by the commissioner one that a reasonable decision-maker could not reach?

\section{Conclusion}

Even individuals who believe that the ideal of a world in which all human being are fully able to enjoy fundamental human rights represents an unlikely utopia might be inspired to try to make choices that "do no harm" and that will minimize the experience of human rights abuses across the globe (DeLaet, 2006).

The human capital content of the occupational structure is increasing, notwithstanding segmentation. Given the enduring nature of the forces driving them, all these changes are likely to continue over the rest of this decade (Rajan, 1987). An effective internal communication strategy and a constructive relationship between the negotiation parties are essential (Landis et al., 2005). The Constitutional court judgment constituted the final stage in the lengthy road traveled by the employer and employee parties to an unfair dismissal dispute. The law and principles pertaining to dismissals have undergone significant changes over the past fifteen years, mainly because of the intervention of the courts, in order to 
ensure the job security of an employee.

As long as economic activity takes place in society, we will find that labour relations are topical. The field of labour is probably one of the most dynamic areas in society, and as we move into a new era in our history, new problem and opportunities will present themselves (Levy, 1992).

\section{References}

Ackermann, M. and Britz, H. (2206) Information, Ethics and the Law, (1st ed), Van Schaik.

Barker F (1999) The South African Labour Market Critical Issues for Renaissance, Van Schaik..

Beckman, J.A. (2005) Affirmative Action An Encyclopedia, Vol. 1; A-I Greenwood Press London.

Bezuidenhout, M.C., Garbers, C.J. and Potgieter, S. (1999) Managing for Healthy Labour Relations; A practical guide for health services in Southern Africa, Van Schaiks.

Cheadle, M.H. et al. (2002) South African Constitutional Law: The Bill of Rights, Butterworth.

Landis, H. Grossett, L. (2005) Employment and the Law: A practical guide for the Workplace, Juta.

DeLaet, D.L. (2006) The Global struggle for Human Rights- Universal Principles in World Politics, Thomson.

Devenish, G.E., Govender, K. and Hulme, D. (2001) Administrative Law and Justice in South Africa, Butterworths.

Finnemore, M. (1999) Introduction to Labour Relations in South Africa, Butterworths Durban.

Grogan, .J (1999) Workplace Law , (4th ed) Juta \& Co Ltd.

Grossett, M. (2002) Discipline and Dismissal (2nd ed) Oxford Press.

Holman, D. Wall, T.D. and Clegg, C.W. (2005) The Essentials of the New Workplace a guide to the Human Impact of modern working practices, John Wiley and Sons, UK.

Kantor, P. (2001) CCMA A Commentary on the Rules Peter Kantor.

Levy, A. (1992) Rights at Work - A guide for Employees, Juta.

Mubangizi, J.C. (2004) The Protection of Human Rights in South Africa A legal and Practical Guide, Juta.

Nel, P.S. (2002) South African Employment Relations Theory and Practice, (4th ed), Van Schaik.

Poolman, T. (1985) Principles of Unfair Labour Practice Juta \& Co Ltd.

Rajan, A. (1987) Services- The second Industrial Revolution? Great Britain.

Rudd, C. (2005) Van Zyl Rudd's Annual Labour Law Review Port Elizabeth Van Zyl, Rudd \& Associates (Pty)Ltd.

Van Jaarsveld, S.R. and Van Eck, B.P.S. (1998) Principles of Labour Law Butterworths Durban.

Van Zyl Rudd and Associates (2008) 24th Annual Seminar, Labour Law Reports (SALLR).

\section{Cases}

Du Preez v Truth and Reconciliation Commission 1996 (8) BCLR 1123 (C).

President of the RSA and Others v SA Rugby Football Union \& Others 1999 (4) SA 147 (CC)

Ivan Myers v National Commissioner of the South African Police Service, The Safety and Security Sectoral Bargaining Council and Coen de Kock NO Unreported case no 425/2012

Sidumo and Congress of SA Trade Unions v Rustenburg Platinum Mines Ltd, the CCMA and Moropa NO (2208) 19 SALLR 35 (CC).

British Leyland UK Ltd v Swift (1981) IRLT 91

\section{Legislation}

Basic Conditions of Employment Act 75 of 1997

Companies Act 61 of 1973

Employment Equity Act 55 of 1998

Employment Protection (Consolidated) Act of 1978

Labour Relations Act 66 of 1995.

Local Government: Municipal Systems Act 32 of 2000

Promotion of Administrative Justice Act No.3 of 2000.

Regulation of Gatherings Act 205 of 1993

Supreme Court Act 50 of 1959

The Constitution of the Republic of South Africa, 1996. 